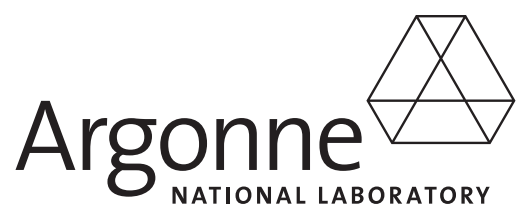

\title{
Summary Report on Safety and Licensing Strategy Support for the ABR Prototype
}

Nuclear Engineering Division 


\begin{abstract}
About Argonne National Laboratory
Argonne is a U.S. Department of Energy laboratory managed by UChicago Argonne, LLC under contract DE-AC02-06CH11357. The Laboratory's main facility is outside Chicago, at 9700 South Cass Avenue, Argonne, Illinois 60439. For information about Argonne, see www.anl.gov.
\end{abstract}

\title{
Availability of This Report
}

This report is available, at no cost, at http://www.osti.gov/bridge. It is also available on paper to the U.S. Department of Energy and its contractors, for a processing fee, from:

U.S. Department of Energy

Office of Scientific and Technical Information

P.O. Box 62

Oak Ridge, TN 37831-0062

phone (865) 576-8401

fax (865) 576-5728

reports@adonis.osti.gov

\begin{abstract}
Disclaimer
This report was prepared as an account of work sponsored by an agency of the United States Government. Neither the United States Government nor any agency thereof, nor UChicago Argonne, LLC, nor any of their employees or officers, makes any warranty, express or implied, or assumes any legal liability or responsibility for the accuracy, completeness, or usefulness of any information, apparatus, product, or process disclosed, or represents that its use would not infringe privately owned rights. Reference herein to any specific commercial product, process, or service by trade name, trademark, manufacturer, or otherwise, does not necessarily constitute or imply its endorsement, recommendation, or favoring by the United States Government or any agency thereof. The views and opinions of document authors expressed herein do not necessarily state or reflect those of the United States Government or any agency thereof, Argonne National Laboratory, or UChicago Argonne, LLC.
\end{abstract}




\section{Summary Report on Safety and Licensing Strategy Support for the ABR Prototype}

by

J.E. Cahalan

Nuclear Engineering Division, Argonne National Laboratory

September 15, 2007

work sponsored by

U. S. Department of Energy,

Office of Nuclear Energy, Science and Technology
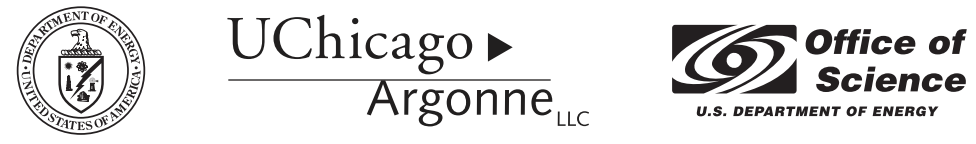

A U.S. Department of Energy laboratory managed by UChicago Argonne, LLC 


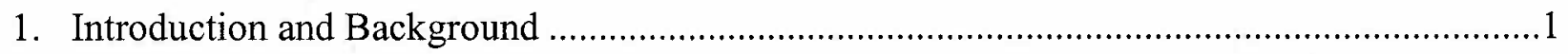

2. Evaluation of Licensing Alternatives............................................................................2

2.1 NRC Licensing under 10 CFR Part 50 ..................................................................2

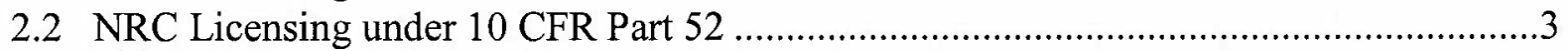

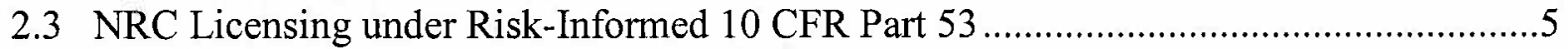

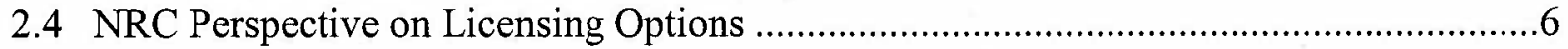

3. Technical Implications of Licensing Paths ...................................................................

3.1 SFR Design, Safety Characteristics, and U.S. Operating Experience .............................7

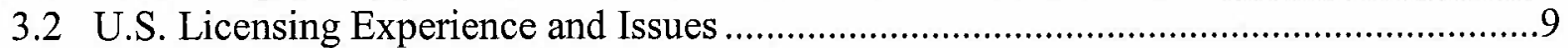

3.3 ABR Design, Analysis, and Documentation Issues for Licensing ..............................11

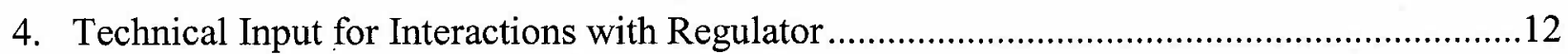

4.1 December 12, 2006, Meeting at DOE-Germantown ...........................................13

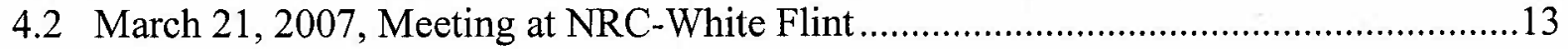

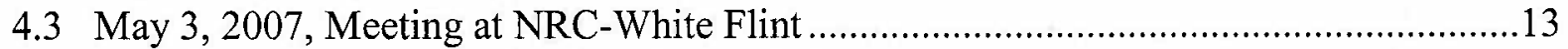

4.4 June 21, 2007, Meeting at NRC-White Flint ......................................................... 14

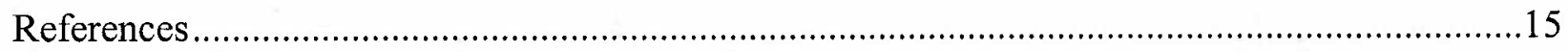

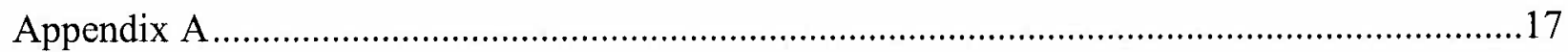




\section{Introduction and Background}

Argonne National Laboratory is providing support to the U.S. Department of Energy in the Global Nuclear Energy Partnership (GNEP) in certification of an advanced, sodium-cooled fast reactor. The reactor is to be constructed as a prototype for future commercial power reactors that will produce electricity while consuming actinides recovered from light water reactor spent fuel. This prototype reactor has been called the Advanced Burner Reactor, or ABR, and is now often referred to as the advanced recycle reactor.

As part of its activities, Argonne is providing technical services to assist definition of a safety and licensing strategy for the ABR prototype, and to further implementation of the strategy. In FY06, an organizational meeting was held for DOE and its laboratory contractors to discuss licensing alternatives and review previous licensing experience for the Fast Flux Test Facility (FFTF) and the Clinch River Breeder Reactor Plant (CRBRP). Near the end of FY06, a report [1] summarizing the discussions and conclusions was written. One of the top-level conclusions recorded in the report was a recommendation to follow a licensing strategy that included the U.S. Nuclear Regulatory Commission (NRC) as the regulatory review and licensing authority.

In FY07, activities at Argonne to support safety and licensing progress have continued. These activities have focused on further evaluation of licensing alternatives; assessment of design, analysis, and documentation implications of licensing paths; and initial technical interactions with the Nuclear Regulatory Commission. This report summarizes FY07 activities.

Current considerations of available NRC licensing alternatives for the ABR indicate that the basic technical design and safety requirements may be based upon those identified in prior U.S. regulatory experiences (i.e. $10 \mathrm{CFR}$ Part 50), updated to reflect recent administrative options made available by new NRC rules (i.e. 10 CFR Part 52).

The design, analysis, and documentation requirements for a particular licensing path are set by statute. For $A B R$, the potential role of passive features in the overall safety design basis may contribute to the analysis and documentation needs. In addition, Probabilistic Risk Assessment (PRA) will play a significant role in establishing the ABR safety design basis.

Because the $A B R$ prototype designer and constructor are not yet determined, formal licensing interactions with NRC must currently be limited to consideration of conceptual design bases and the technological readiness of the sodium fast reactor industry to proceed. To address these issues, an introductory meeting between NRC and DOE was held at which the status of current regulatory requirements was reviewed by NRC, and the status of the GNEP/ABR project was summarized by DOE. Selected reviews of the history of sodium fast reactor projects in the U.S. and the current status of technology were summarized at this meeting by DOE laboratory staff. As a result of these discussions, it was recognized that the program would benefit from further technical interactions between NRC and DOE laboratory technical staff. To that end, a series of technical information meetings were planned in which knowledgeable DOE laboratory researchers could communicate up-to-date technology status reports to NRC staff. This series of information exchange meetings is partially covered by Work Package PAN07ABTD03, Knowledge Management. 


\subsection{Evaluation of Licensing Alternatives}

In FY2006, Wigeland [1] discussed the licensing options for the proposed Advanced Burner Test Reactor (ABTR) and the Advanced Burner Reactor prototype (ABR, now known as the Advanced Recycle Reactor). At that time, the ABTR was proposed as a small ( $250 \mathrm{MWt})$ test reactor capable of producing electricity, and located at or near a USDOE site. Given its mission, it was envisioned that the ABTR could be licensed either by NRC or could be self-regulated by DOE. As GNEP program plans developed, the concept of the first ABR as a prototype demonstration reactor evolved, followed in subsequent years with a fleet of commercial recycle reactors. With the development of the ABR prototype concept, the licensing strategy for advanced recycle reactors narrowed to consideration of NRC as the responsible regulatory agency, given the commercial mission of the $\mathrm{ABR}$ as a large transmutation reactor connected to an electrical generation station. From that refocused perspective, this section identifies and describes the NRC licensing process options currently viewed as relevant for the ABR prototype.

In the earlier report, Wigeland [1] noted the regulatory responsibilities of the NRC under the National Environmental Policy Act (NEPA) as implemented in 10 CFR Part 51, and the requirements for evaluation of a reactor site in 10 CFR Part 100. The radiological source term used to evaluate a reactor site is a key measure of site suitability. Current commercial Light Water Reactors (LWRs) have used a source term specified in TID-14844. Regulations for new LWR plants allow an alternative source term formulation. However, it is clear that the site suitability source term appropriate for a sodium-cooled transmutation reactor will be different than that characterized by the current NRC regulations for LWRs. Definition of a radiological source term that is appropriate for ABR may involve significant technical effort by the applicant, as well as intensive review by NRC. Consequently, preliminary consideration of the ABR source term has been initiated in current ABR NEPA-related work packages. The status of that work is reported elsewhere.

\subsection{NRC Licensing under 10 CFR Part 50}

All of the nuclear power plants currently operating in the United States have been licensed by the Nuclear Regulatory Commission (NRC) [2, 3] according to the two-step process described in Title 10 of the Code of Federal Regulations under Part 50 (10 CFR Part 50) [4]. This process first entails issuance of a construction permit, followed later by granting an operating license. Under 10 CFR Part 50, the applicant receives a construction permit following NRC review of the safety of the proposed plant based on the preliminary design and the suitability of the proposed site. Upon completion of the final detailed design and operating procedures, NRC reviews the submitted documentation for compliance with safety and environmental requirements and issues an operating license.

An application for a construction permit must contain a) a preliminary safety analysis report, b) an environmental impact report, and c) documentation of financial competence and compliance with antitrust regulations. Once accepted for review, the NRC hosts a public meeting near the proposed site to allow public comment. NRC staff review of the application includes compliance assessment with applicable regulations for site characteristics, plant design, plant response to hypothetical accidents, plant operations, environmental impacts, and emergency 
plans. The NRC documents its review in a Safety Evaluation Report and a Draft Environmental Impact Statement. The Advisory Committee on Reactor Safeguards (ACRS) also reviews the application and reports its findings in a letter to the Chairman of the NRC. The Atomic Safety and Licensing Board (ASLB) holds a public hearing to allow written and oral statements to be entered into the official record. NRC can authorize some construction work at the site before issuance of the construction permit by granting a Limited Work Authorization (LWA) following environmental review of the site.

Following issuance of the construction permit, the applicant proceeds with initial construction, and completes the detailed design and operating procedures. Based on this information, the applicant submits an operating license application, which includes a Final Safety Analysis Report (FSAR). NRC documents its review of the FSAR in a Final Safety Evaluation Report, and the ACRS performs an independent evaluation of the FSAR and the NRC staff review.

The 10 CFR Part 50 process is tailored for current light water reactor (LWR) designs. For example, the general design criteria in 10 CFR Part 50 Appendix A are written with explicit reference to LWR design features and operating conditions. Nevertheless, the 10 CFR Part 50 process was applied to consideration of the construction permit application for the sodiumcooled Clinch River Breeder Reactor Plant (CRBRP) and other non-LWR designs. These nonLWR applications of 10CFR Part 50 were accomplished in case-by-case agreements between the $\mathrm{NRC}$ and the applicants to interpret the regulations and to satisfy regulatory intent with suitable design features and operating procedures.

For ABR, the 10 CFR Part 50 process offers the advantage of being an established process in which the procedural paths are well known and tested. It was the process used in the licensing reviews for the Fast Flux Test Facility (FFTF) [5] and the Clinch River Breeder Reactor Plant (CRBRP) [6], and the pre-application reviews of the SAFR [7] and PRISM [8] concepts.

\subsection{NRC Licensing under 10 CFR Part 52}

In 1989, NRC established an alternative, one-step licensing process [2, 3] under 10 CFR Part 52 [4], with explicit provisions for a combined (construction and operating) licensing process, an early site permit process, and a standard plant design certification process. An application submitted under 10 CFR Part 52 for a combined construction and operating license may include by reference a standard design certification, an early site permit, both, or neither. (If neither an early site permit nor a certified design is included by reference, the application is reviewed as for the 10 CFR Part 50 two-step process). However, the application must include essentially the same information required by 10 CFR Part 50 . The objective of the one-step licensing process is to streamline the proceedings by reducing the review effort for a particular application that includes by reference a previously reviewed site (early site permit) or a standard plant design (design certification permit).

Under 10 CFR Part 52, an applicant may receive an early site permit that resolves site safety, environmental protection, and emergency preparedness issues independent of a specific nuclear plant design. The application must provide information on site boundaries, site characteristics (seismic, meteorologic, hydrolic, geologic), proximate facilities (industrial, military, 
transportation), proximate population (current and projected), alternative site evaluations, site plant locations and characteristics (number, type, power level), maximum thermal and radiological discharges, cooling systems characteristics, radiological dose and hypothetical accident consequences, and emergency plans. The NRC documents its review of the early site permit application in a safety evaluation report, and in draft and final environmental impact statements. The process provides for a limited work authorization to perform non-safety site preparation activities prior to issuance of a combined license. Following safety reviews by NRC staff and the ACRS, the ASLB holds hearings to allow public comment. When granted, the early site permit is valid for no less than 10 years and no more than 20 years, and can be renewed for an additional 10 to 20 years. As of this writing, early site permit applications for four commercial LWR sites have been submitted, and two have been approved.

Under 10 CFR Part 52, an applicant may seek certification of a reactor design through the NRC rulemaking process. The design certification applies to the reactor and plant design, and is independent of a specific site. Once the design is certified, it may be included by reference in any combined license application for a period of 15 years. The application for design certification must include proposed inspections, tests, analyses, and acceptance criteria (ITAAC), and must demonstrate compliance with applicable regulations. The application must present a complete nuclear plant design, lacking only site-specific design features such as heat sinks. The application must present the design basis, limits on operation, and safety analyses. The level of detail in the safety analyses is required to be the equivalent of that found in a Final Safety Analysis Report (FSAR). The NRC staff reviews the application and prepares a Safety Evaluation Report (SER) that describes how the design meets the requirements. The ACRS reviews the application and the staff SER and holds a public meeting. Upon determining that the application is acceptable, the NRC drafts a final design certification rule, which becomes an appendix to $10 \mathrm{CFR}$ Part 52. Issues resolved in a design rulemaking certification are subject to more restrictive change procedures than those resolved in other licensing processes, so a design certified under 10 CFR Part 52 can be changed by subsequent NRC determinations only in limited circumstances. At the time of this writing, one commercial LWR design has been certified, another is in the review process, and five additional power reactor designs (three LWRs and two non-LWRs) are in pre-licensing.

The provisions in 10 CFR Part 52 for a combined construction and operation license utilizing an early site permit and/or a certified design promise a more efficient and predictable licensing process than the two-step process of 10 CFR Part 50 for situations in which multiple plants are constructed at a single site, or in which a certified design is to built at many sites. For ABR, the design certification process offers schedule benefit for plants built after the first plant, and early site permitting offers benefits if multiple plants are built at a single site. Additional licensing effort will be required for ABR compared to LWRs because the current 10CFR Part 50 safety requirements are written in terms of LWR designs, and these requirements hold for 10CFR Part 52 safety evaluation. Further licensing effort would be necessary for ABR design certification, and it will be necessary to weigh the benefits of licensing by rulemaking (more resistant to postlicensing NRC-imposed design changes) against the added cost of design certification.

10 CFR SubPart 52. 47(b)(2)(i) presents additional application content requirements for design certification of plants like ABR whose design differs significantly from the current generation of 
LWRs. These requirements apply to qualification of safety systems by analysis and testing, and provide for full-scale testing in an appropriately sited and sized prototype.

\subsection{NRC Licensing under Risk-Informed 10 CFR Part 53}

The NRC is currently engaged $[9,10]$ in an effort to update existing licensing regulations to include risk-informed and performance-based requirements. Recently, the NRC staff has proposed a new approach that would change the objective from an update of specific existing regulations to development of a new set of comprehensive risk-informed and performance-based requirements applicable for all nuclear power technologies. The stated goal of the new rule would be to "...take advantage of operating experience, lessons learned from the current rulemaking activities, advances in the use of risk-informed technology, and would focus NRC and industry resources on the most risk-significant aspects of plant operations to better ensure public health and safety." [11] According to current documentation, the new requirements would be codified as a new 10 CFR Part 53.

Under 10 CFR Part 53, the regulatory process would integrate safety, security, and emergency preparedness requirements. Levels of safety would be quantified in terms of risk, and subsidiary risk objects would be developed (e.g. $10^{-5}$ /plant year for prevention of major fuel damage, and $10^{-6} /$ plant year for prevention of offsite radioactive release leading to one or more early fatalities). The risk associated with siting of new plants at locations with existing reactors or siting of multiple reactors at one location would be quantified in terms of the integrated risk. New containment functional performance requirements would be developed taking into account such features as core, fuel, and cooling system design. The technical basis for Part 53 would be expressed in terms of technology-neutral framework. A new policy statement on defense-indepth would be developed that includes consideration of technology-neutral and risk-informed elements.

In 2006, the NRC commissioners directed [9] that an Advanced Notice of Proposed Rulemaking (ANPR) be prepared and comments from stakeholders and the public should be collected. The ANPR was published in the Federal Register on May 4, 2006, as 71 FR 26267 [11], with a comment closing date of December 29, 2006. Meetings were held with stakeholders and the public, and NRC staff met with the ACRS to discuss technical issues. The NRC staff prepared a detailed analysis of the submitted comments, and reported their findings to the Commissioners; the findings are summarized in a Commission letter [10] dated June 14, 2007. In general, the collected comments do not support new rulemakings to revise 10 CFR Part 50 in the near term, but do support continued development of risk-informed requirements for new reactors. The comments indicated the need for further development of the technology-neutral framework concept, and suggested testing the concept by application to a specific new reactor design. The comments were generally inconclusive to negative regarding the new policy statement elements of the ANPR. In response to the stakeholder comments, the NRC staff committed to publish the technology-neutral framework as a NUREG after consideration of the stakeholder and ACRS comments, and to initiate efforts to develop a policy statement on defense-in-depth for Commission consideration. Further, the staff recommended deferral of new rulemaking for revision of risk-informed and performance-based 10 CFR Part 50 requirements until after 
development of the Next Generation Nuclear Plant (NGNP) licensing strategy or the receipt of a licensing application for design certification for the Pebble Bed Modular Reactor (PBMR).

Based on current NRC staff recommendations and Commission directives, new licensing procedures and requirements under $10 \mathrm{CFR}$ Part 53 will not be available in the near term. However, development of such requirements should be monitored by ABR designers and safety specialists for relevance to ABR prototype licensing.

\subsection{NRC Perspective on ABR Licensing Options}

In May, 2007, NRC staff delivered a whitepaper [12] to the NRC Commissioners summarizing four options for licensing of GNEP facilities, including both the fuel reprocessing facility (CFTC) and the ABR. For ABR, the four options were 1) use existing Part 50, with exemptions, as necessary, or a suitably modified and adapted Part 52 process, to address sodium-cooled fast reactor technology, 2) create a new regulation specific to advanced recycling reactor (Part $5 \mathrm{X}$ ), 3) develop a specific GNEP regulation applicable to both fuel reprocessing and recycle reactors (10 CFR Part XX), or 4) solicit public and stakeholder comments on GNEP licensing framework attributes and then decide on either issuing an order or making a new rule for licensing requirements. The NRC staff recommended beginning with the first option (modified Part 50 or 52) in a phased approach that considered the technical bases for CFTC and ABR in Phase I, including a gap analysis on Part 50 for applicability. In Phase II, the staff would transition to the third option in development of a new GNEP-specific regulation.

After deliberation, the Commissioners directed the staff to proceed only with Phase I of the first option $[13,14]$. This work includes development of the regulatory framework by preparing the technical basis documentation to support revisions to Part 50, and a gap analysis to identify changes in regulatory requirements necessary to license an advanced recycle reactor. The results of this work are to be delivered after the June 2008 Secretarial GNEP decision, and after FY 2009 GNEP appropriations are determined by Congress. The Commissioners specifically directed the staff to not proceed with the third option in FY 2009. For FY 2007, NRC staff resources will be limited to initiate Phase I, with one or two FTEs in FY 2008 to conduct a first order gap analysis. For the advanced recycle reactor gap analysis, the Commissioners directed the staff to use Clinch River licensing requirements as the starting point, and to tabulate "what rules apply, what rules clearly do not apply and whether a gap exists and its relative size or complexity." The staff guidance specifically forbids execution of a phenomena and ranking table analysis, citing an absence of adequate definition of the GNEP program scope and technology to be employed. 


\subsection{Technical Implications of Licensing Paths}

The selection of the licensing path for the ABR prototype will require specific technical activities depending on the design of the reactor and the safety approach employed by the designer. This section summarizes previous sodium fast reactor designs and the associated technical issues encountered in the related licensing activities, and suggests potential issues the for ABR prototype.

\subsection{SFR Design, Safety Characteristics, and U.S. Operating Experience}

Consideration of liquid-metal-cooled fast reactors for production of fuel and electricity date to April, 1944, when Enrico Fermi and Leo Szilard [15] discussed the concept of a compact, fastspectrum nuclear reactor. The fast spectrum was needed to capitalize on the increase of fission neutron yield with incident neutron energy, and the compact design was desired to economize on the inventory of fissile fuel and optimize the reactor geometry for the fast spectrum. (Accumulation of fissile material was a major focus at the Metallurgical Laboratory). Fissile fuel production was based on the $\mathrm{U}^{238} / \mathrm{Pu}^{239}$ cycle. Liquid metal coolant was proposed as an efficient heat removal medium for the high power density associated with the compact design, with leadbismuth alloy and sodium identified as candidates. The lower pumping power of the lighter sodium and its superior chemical compatibility with steel later favored sodium as a coolant, in addition to its capability to provide a significant temperature margin to coolant boiling at atmospheric pressure (low operating pressure).

Through the years, the design of a prototypic sodium-cooled fast reactor evolved to include fuel elements consisting of small cylindrical metal fuel pins cast from the metal or stacks of cylindrical fuel pellets sintered from the oxide, enclosed within a cylindrical cladding of stainless steel. The total height of the fuel is typically a meter, with another meter of empty cladding provided for collection of fission gases released during irradiation. The cladding outer diameter is typically 6 to $8 \mathrm{~mm}$. Groups of fuel elements are arranged on a close-packed triangular array, spaced apart by a cylindrical wire wrap, and bottom-supported within a hexagonal duct to form a fuel subassembly. The fuel subassemblies are typically several meters long, including entrance and exit fixtures and internal shielding. Sodium coolant flows vertically upward within the duct through the subchannels formed by the neighboring fuel elements. Coolant flows past the fuel elements with a relative high velocity $(5$ to $6 \mathrm{~m} / \mathrm{s})$ to remove heat, and the temperature of the coolant increases by approximately $150^{\circ} \mathrm{C}$. Each fuel subassembly typically produces a few megawatts or more of power in normal operation, and many subassemblies are grouped together to form the reactor core.

Reactor sodium absorbs neutrons to form radioactive $\mathrm{Na}^{24}$, which decays with a 15 hour half-life. In addition, the selection of sodium as coolant brought a concern for coolant leaks leading to chemical interactions with air or water. Consequently, plant designs usually have provisions for multiple barriers (defense-in-depth) to hold the radioactive reactor coolant. Furthermore, designs provide for heat removal through an intermediate heat exchanger to a second, low pressure sodium loop that carries heat to the steam generator. The intermediate sodium loop isolates the radioactive reactor coolant and also provides a barrier between the high pressure steam in the power conversion circuit and the low pressure reactor. In pool-type plant designs, all the 
radioactive sodium is contain within a single tank, which also contains the reactor coolant pumps and the intermediate heat exchangers. In loop-type plant designs, only the reactor core is contained in the reactor vessel, which is connected to pumps and intermediate heat exchangers through pipes.

Early safety concerns arose from the relative high fissile content $(\sim 20 \%)$ fuel inventory, and the associated sensitivity of the reactor nuclear characteristics to fuel relocation, since further compaction of fuel beyond its design configuration could lead to substantial reactivity and power increases. Due to the high power density of the fast reactor core, interruption of coolant flow at power can lead to fuel melting and cladding damage within seconds. Sodium over-heating and boiling will lead to large scale voiding and loss of heat removal at the low operating pressure. In addition, coolant voiding in large reactor designs can introduce positive reactivity, and lead to power excursion. These issues were addressed in an advanced reactor development program that supported the design and construction of EBR-I [16], EBR-II [15], FERMI-1 [17], SEFOR [18], and FFTF [19].

EBR-I [16] was a 1.4 MWt NaK-cooled experimental reactor built at the Idaho National Reactor Testing Station (NRTS) to demonstrate breeding and produce electricity ( $200 \mathrm{~kW})$. Construction began in 1949, first production of electricity was in 1951, and demonstration of breeding was achieved in 1952. In 1955, during an experiment at low power and coolant flow to investigate reactivity feedback effects, an unplanned reactor power excursion resulted in fuel melting. Postaccident analyses indicated that the excursion was caused by a design feature that in some circumstances caused fuel element bowing with a prompt positive reactivity effect. The design flaw was remedied in the replacement fuel design, and the lesson learned was applied to all subsequent liquid metal fast rector designs. The fuel was replaced, and EBR-I continued to operate until 1963.

EBR-II [15] was a $62.5 \mathrm{MWt}$ prototype breeder power station built at Argonne National Laboratory-West to demonstrate closure of the fast reactor fuel cycle, including fuel reprocessing and recycling. EBR-II operated successfully from 1964 to 1994, demonstrating fuel reprocessing in the adjacent Fuel Cycle Facility in 1964 and fuel recycle in 1965. In 1969, the mission of EBR-II changed to fuel irradiation and testing, and in the mid-1980's it began service as the prototype for the Integral Fast Reactor (IFR) program. From 1984 to 1986, a series of shutdown Heat Removal Tests (SHRT) was conducted at EBR-II, demonstrating that liquid metal fast reactors were capable of 1 ) removing decay heat by natural circulation, and 2) providing inherent self protection against fuel damage in unprotected (without scram) loss-of-flow and loss-of-heatsink accidents.

FERMI-1 [17] was a $200 \mathrm{MWt}$ power station built by Detroit Edison on the western shore of Lake Erie that first produced power in 1966. During power ascension in October, 1966, an unplanned inlet subassembly flow blockage caused fuel melting in three subassemblies. Subsequent investigation showed that the coolant flow blockage was caused by an insecurely fastened inlet plenum liner plate that came loose during startup and was swept along with the coolant flow, covering the single subassembly inlet port. The reactor fuel was replaced and the plant continued operation until 1972. The most important lesson learned from the FERMI-1 
accident was the need for multiple coolant entrance paths for the subassembly, and this design feature ahs been incorporated in all subsequent liquid metal fast reactor designs.

The $20 \mathrm{MWt}$ Southwest Experimental Fast Oxide Reactor (SEFOR) [18] was built in Arkansas and began operation in 1969. The mission of SEFOR was to demonstrate the fuel Doppler reactivity effect for oxide fuel in sub- and super-prompt critical power excursions. The experiment program was successfully completed in 1972.

The 400 MWt Fast Test Reactor (FTR) in the Fast Flux Test Facility (FFTF) [19] was built at Hanford to serve as a fuels, materials, and components testing facility. Power operation began in 1980 and continued until 1993 when the advanced reactor development program ceased. Testing of fuels at FFTF included verification of fuels for the planned Clinch River Breeder Reactor Plant (CRBRP), and development of advanced, low-swelling cladding materials for high burnup fuels. FFTF also served as a test bed for large-scale components (pumps, vessels, heat exchangers) for CRBRP. The mission of FFTF was extended to include demonstration of natural circulation shutdown heat removal, and in 1986 a series of safety tests was conducted to demonstrate passive power reduction in unprotected loss-of-flow transients.

\subsection{US Licensing Experience and Issues}

Wigeland [1] has discussed the licensing experience for the FFTF operating license [5], for the CRBRP construction permit [6], and for the pre-application review of PRISM [8]. (The issues identified in the pre-application review of PRISM largely include the issue raised in the review of the SAFR concept [7], which was contemporaneous with PRISM). All of these proceedings were carried out under the then-current requirements of 10 CFR Part 50, modified on a case-bycase basis for relevance to the sodium-cooled fast reactor design at hand. The discussions for FFTF, CRBRP, and PRISM will be expanded here to focus on design-related issues with potential relevance to $A B R$.

A detailed discussion of FFTF safety and regulatory issues has been proved by Simpson and his colleagues $[20,21,22]$ from the viewpoint of the applicant. As an AEC/ERDA/DOE facility, FFTF was not required to obtain a license from NRC, since authorization for construction and operation was the responsibility of AEC/ERDA/DOE. However, detailed reviews of the design and operation of FFTF were performed by NRC staff and ACRS and a safety evaluation report was issued by NRC in 1978 [5]. In the course of those reviews, a great deal of regulator attention was devoted to designed systems for mitigation of severe accident consequences. To address the issues raised, the applicant performed significant studies to characterize the consequences of Hypothetical Core Disruptive Accidents (HCDAs), and to evaluate the ability of the design as proposed to prevent uncontrolled releases of radioactive materials. In addition, the enhancement of containment margins provided by certain regulator-proposed mitigation features was analyzed. These additional systems included, at various times during the review process: 1) an sealed barrier (dome) over the reactor vessel head to provide additional margin against the consequences of coolant spills and fission gas release to the containment building as a consequence of an HCDA, 2) a provision for an ex-vessel core catcher beneath the reactor cavity, and 3) development of filtering technology for possible addition of equipment for controlled releases from the containment. The applicant successfully demonstrated by analyses that the 
bounding consequences of HCDAs were well characterized with respect to coolant spills and fission gas releases from the primary system, that the design as proposed provided containment of severe accident consequences, and that an additional containment dome would not significantly improve containment margins. With respect to the need for an ex-vessel core catcher, the applicant maintained that the core debris from an HCDA would be contained indefinitely within the reactor vessel (cooled and subcritical). However, analyses were performed to assess the containment performance for deposition of core debris into the vessel cavity region, without and with active ex-vessel debris retention design features. The applicant concluded that inclusion of an ex-vessel core catcher was inappropriate given a) the low probability of the HCDA, b) the potential for in-vessel retention, c) the limited probability that ex-vessel retention could be achieved if in-vessel retention was not successful, d) the existence of large containment margins in the proposed design, and e) the cost and schedule impacts associated with the R\&D needed to develop a core catcher design with assured performance. The NRC staff was critical of the applicant position, but agreed with continued construction so long as the option to include an ex-vessel core catcher in the future was not precluded. The applicant agreed to this allowance and construction proceeded. Lastly, although the applicant expressed confidence in the containment margins, it was agreed to continue examination of the technical data relevant to vented containment design and effectiveness of filtering controlled releases.

The Clinch River Breeder Reactor Plant (CRBRP) was intended to be the prototype demonstration design for the U.S. Liquid Metal Fast Breeder Reactor (LMFBR) program. A construction permit for CRBRP was obtained from NRC under 10 CFR Part 50, but the project was terminated prior to construction. Strawbridge and his colleagues [23, 24, 25] have reported the technical aspects of the interactions with the $\mathrm{NRC}$ from the perspective of the applicant. As a commercial power reactor, CRBRP designers adopted a safety design approach that was fully consistent with conventional defense-in-depth practices applied in the LWR industry. This included design for safety in reactor shutdown, residual heat removal, and containment systems, plus engineered systems with special relevance to sodium coolant, such as sodium leak detection systems. In addition, early in the licensing interactions, the applicant and the regulatory agreed that core melt accidents would not serve as part of the plant safety design basis, but rather that engineered safety systems would be employed to reduce the likelihood of severe accident to a level that justified their exclusion. These systems included two safety-grade reactor shutdown systems, two safety-grade shutdown heat removal systems with additional backup systems, and a large-volume, high-strength containment building with provision for filtered venting. Nevertheless, licensing interactions included consideration of severe accidents. The applicant prepared a probabilistic risk assessment [26] which showed that the risk from severe accidents was small compared to the overall risk to public health and safety. Deterministic analyses were performed by the applicant to show the thermal and structural margins beyond the design basis for mitigation of severe accident consequences. Independent analyses were performed by NRC specialists [27]. At the time the construction permit was granted, the CRBRP design did not include safety design features specifically intended for core melt mitigation (i.e. core catcher).

During the USDOE Advanced Liquid Metal Reactor (ALMR) program, innovative reactor conceptual designs were proposed that utilized passive, inherent mechanisms to fulfill the traditional defense-in-depth safety design requirements. The most high developed of the designs 
was proposed by General Electric as the PRISM concept. The PRISM conceptual design evolved over a period of years, with changes in reactor core power level and design. NRC performed a pre-application review of the PRISM concept [8], and the design engineer provided a perspective on the regulatory interactions [28]. The PRISM concept included several aggressively innovative design features in the safety design basis. Emergency decay heat removal was provided by a single safety-grade reactor guard vessel cooling system that employed natural circulation of ambient air. Normal shutdown cooling (not safety grade) was provided through the normal heat rejection system, supplanted by auxiliary forced air cooling of the steam generator shell. A single safety-grade reactor shutdown system (control rods) was employed, with multiple activation and actuation systems. Inherent core reactivity feedbacks for fission power regulation in Anticipated Transients Without Scram (ATWS) provided back-up to the active shutdown system. Lastly, the concept included a small-volume steel shell over the reactor vessel head for containment, not dissimilar to the head cavity dome once proposed for FFTF, but without a conventional large, strong containment building. NRC review of the concept [8] reserved endorsement of the safety design basis, and expressed the need for a conventional containment design and for traditional (multiple, diverse, independent) safety-grade systems for residual cooling and reactor shutdown. The designer proposed modifications of the concept [28] to address NRC concerns, but a number of unresolved issues remained at the time of the ALMR program termination.

\subsection{ABR Design, Analysis, and Documentation Issues for Licensing}

Consideration of the FFTF, CRBRP, and PRISM experience provides insight into the expected NRC technical stance in consideration of ABR prototype regulation. It is reasonable to expect that the ABR prototype will be subject to technical safety requirements grounded in the regulatory intent of the provisions of $10 \mathrm{CFR}$ Part 50, with specific requirements adjusted to address the relevant characteristics and operating conditions of a sodium-cooled fast reactor. Examination of the LWR General Design Criteria (GDC) in Appendix A of 10 CFR Part 50 reveals the top level design requirements likely for the ABR prototype, consistent with a traditional defense-in-depth approach: a) a low-leakage containment design, capable of providing protection against uncontrolled radiological releases from coolant spills for a specified time consistent with emergency plans and off-site dose rules, b) multiple (at least two), diverse, independent residual heat removal systems, capable of maintaining systems temperatures below thresholds for breach of radiological barriers (cladding, primary coolant system, containment), and c) multiple (at least two), diverse, independent reactor shutdown systems, capable of achieving and maintaining reactor subcriticality. Other design features that may be required could include coolant leak detection instrumentation, sodium fire suppression equipment, sodium/concrete spill mitigation measures (cell liners, hydrogen combiners), sodium aerosol mitigation (containment atmosphere control, control room habitability), and filtered containment venting. For sodium-cooled plants, special design consideration will be given to mitigation of steam generator tube rupture consequences, including pressure relief and control systems, hydrogen control, and fire suppression. Considerable technical information is available to support design of sodium fast reactor safety systems from the archives of the LMFBR and ALMR programs, but a modern quality assurance program must be developed and implemented to bring this information to availability for ABR licensing. 
The scope of analyses needed for ABR prototype design certification and licensing can be estimated based on current NRC licensing processes and expectations for design feature requirements and proposals by the industrial vendors. First, it should be noted that all considered licensing paths require establishment of a set of General Design Criteria (GDC) and definition of a spectrum of Design Basis Accidents (DBAs). Results from analyses of the DBAs will be needed to demonstrate that the reactor and plant design performs in compliance with the requirements set by the GDC and with $10 \mathrm{CFR}$ radiological release requirements. The scope of these analyses is usually met in Chapter 15 of the Safety Analysis Report (SAR). Second, current regulations require execution of a Probabilistic Risk Assessment (PRA). The precise scope and detail of the PRA will depend on the selected regulatory process and the role of PRA in that process. For example, regulation by 10 CFR Part 50 (or Part 52) requires a PRA primarily for the purpose of assuring that the probability of core melt is less than accepted standards and is comparable with existing nuclear power plants. However, if a risk-informed approach is selected (e.g. 10 CFR Part 53), the PRA may be used to identify the full spectrum of DBAs (sequences, assumptions, uncertainties), and the scope and detail needed in the execution of the PRA will be significantly increased in comparison to the traditional approach. Finally, previous experiences indicate that analysis effort will be necessary to address and characterize safety issues associated with beyond-design-basis and severe accident performance. These types of analyses have been required in the past to assess the impacts of sodium coolant (e.g. positive coolant void reactivity) and fast reactor (e.g. recriticality) special characteristics, not as a part of the safety design basis but rather to quantify for the regulator the available margin beyond the design basis to uncontrolled radiological releases and risk to public health and safety. Considerable technical information is available to support analysis of sodium fast reactor systems from the archives of the LMFBR and ALMR programs, but a modern quality assurance program must be developed and implemented to bring this information to availability for $A B R$ licensing.

The documentation requirements for licensing of the ABR prototype will consist of 1) preparation of an environmental report (ER), 2) preparation of a safety analysis report (SAR), and 3) preparation of a probabilistic risk assessment (PRA) report, independent of the licensing path. For the two-step process (10 CFR Part 50), preliminary and final versions of the SAR will be required.

\subsection{Technical Input for Interactions with Regulator}

An initial information exchange meeting between NRC and DOE and its laboratory staff was held at DOE-Germantown on December 12, 2006. Discussions at this meeting revealed the desirability for a continuing series of meetings to provide NRC with information on the status of the sodium fast reactor technology, with coverage of performance characteristics for actinide consumption. A list of technical topics to be covered in further meetings was prepared by Argonne and forwarded to NRC and DOE for review. NRC subsequently provided comments and additional topics for consideration. The revised list of topics is provided in Appendix A.

Three subsequent meetings, partially covered by Work Package PAN07ABTD03 - Knowledge Management, have been held at NRC-White Flint with presentations by Argonne research staff. These presentations were video-taped by NRC for future reference. Non-sensitive presentations 
from all meetings are being made available to registered personnel on a worldwide web site at Argonne.

\subsection{December 12, 2006, Meeting at DOE-Germantown}

In this initial meeting, DOE presented an overview of the GNEP program, and identified policy, resource, and infrastructure issues and challenges from the project sponsor's perspective. NRC presented information on potential regulatory approaches and also addressed issues associated with integrated safety analysis, management measures, and quality assurance requirements. DOE laboratory staff presented information on previous sodium fast reactor experience and lessons learned, use of probabilistic risk assessment (PRA) in new facility design, status of materials technology, and ABR prototype driver fuel qualification status.

Discussions of sodium fast reactor technology status in this meeting identified the desirability for further information exchange meetings, prompting preparation of the list of topical areas in Appendix A and the scheduling of presentations by DOE laboratory staff to NRC.

\subsection{March 21, 2007, Meeting at NRC-White Flint}

In the March 21 meeting, Argonne research staff presented introductory information on sodium fast reactor technology (Topic 1a in Appendix A) to NRC staff. The presentation began with an introduction to liquid-metal-cooled reactor (LMR) technology and continued with a summary of U.S. LMR experience, including the EBR-I and EBR-II research facilities at Argonne-Idaho, and the Fast Flux Test Facility (FFTF) at Hanford. Other significant, but not constructed projects included the Clinch River Breeder Reactor Plant, the Rockwell International SAFR design, and the General Electric PRISM design. The design, performance, operational, and safety issues associated with these projects were reviewed, with emphasis on aspects that are relevant to the ABR prototype. Information and experience from the legacy U.S. LMR research and development program were reviewed.

\subsection{May 3, 2007, Meeting at NRC-White Flint}

In the May 3 meeting, Argonne research staff presented technical information on the technology of sodium as a reactor coolant (Topic $1 \mathrm{~b}$ in Appendix A) and on sodium fast reactor physics performance (Topic 2a in Appendix A).

In the sodium coolant presentation, the thermophysical, transport, and chemical properties of sodium were reviewed and compared with water. The relationship of sodium properties to reactor and plant design features was described with emphasis on safety-related performance characteristics. Important contrasts with light water reactor performance and safety design features were highlighted.

In the fast reactor physics presentation, the neutronics performance characteristics of a fast spectrum reactor were reviewed, with consideration of fuel loadings for actinide burning. The presentation covered relevant operational and safety reactor physics issues, including traditional 
safety concerns regarding important reactivity feedbacks such as fuel Doppler and coolant voiding.

\subsection{June 21, 2007, Meeting at NRC-White Flint}

In the June 21 meeting, Argonne research staff presented technical information on sodium fast reactor safety issues (Topic 6 in Appendix A) covering defense-in-depth safety design philosophy, US sodium fast reactor designs, general design criteria, design basis accidents, beyond design basis accidents, severe accidents (coolant void, recriticality, fuel-coolant interactions), passive safety, past safety analysis results (FFTF, CRBRP, SAFR, PRISM), and reactor safety analysis methods. 


\section{$\underline{\text { References }}$}

1. R. A. Wigeland, ABTR Licensing Options and Regulatory Strategy, Private Communication, June 30, 2006.

2. U.S. Nuclear Regulatory Commission, World Wide Web site: www.nrc.gov

3. U.S. Nuclear Regulatory Commission, Nuclear Power Plant Licensing Process, NUREG/BR-0298, Rev. 2, July, 2004.

4. Code of Federal Regulations, Title 10, Energy. See U.S. Government Print Office World Wide Web site: www.access.gpo.gov/nara/cfr/cfr-table-search.html\#page1

5. U.S. Nuclear Regulatory Commission, Safety Evaluation Report related to Operation of the Fast Flux Test Facility, NUREG-0358, August, 1978.

6. U.S. Nuclear Regulatory Commission, Safety Evaluation Report related to the Construction of the Clinch River Breeder Reactor Plant, NUREG-0968, March, 1983.

7. U.S. Nuclear Regulatory Commission, Preapplication Safety Evaluation Report for the Sodium Advanced Fast Reactor (SAFR) Liquid Metal Reactor, NUREG-1369, December, 1991.

8. U.S. Nuclear Regulatory Commission, Preapplication Safety Evaluation Report for the Power Reactor Innovative Small Module (PRISM) Liquid Metal Reactor, NUREG-1368, February, 1994.

9. U.S. Nuclear Regulatory Commission, Staff Plan to Make a Risk-Informed and Performance-Based Revision to 10 CFR Part 50, SECY-06-0007, January 9, 2006.

10. U.S. Nuclear Regulatory Commission, Staff Recommendations Regarding a RiskInformed and Performance-Based Revision to 10 CFR Part 50 (RIN 3150-AH81), SECY07-0101, June 14, 2007.

11. U.S. Nuclear Regulatory Commission, Approaches to Risk-Informed and PerformanceBased Requirements for Nuclear Power Reactors, 10 CFR Parts 50 and 53, RIN 3150 AH-81, May 4, 2006. Published in Federal Register, Vol. 71, No. 86, May 4, 2006. See: http://www.access.gpo.gov/su docs/fedreg/a060504c.html

12. U.S. Nuclear Regulatory Commission, Regulatory Options for Licensing Facilities Associated with the Global Nuclear Energy Partnership, SECY-07-0081, May 15, 2007. See: http://www.nrc.gov/reading-rm/doc-collections/commission/secys/2007/secy20070081/2007-0081scy.html

13. U.S. Nuclear Regulatory Commission, Commission Voting Record, SECY-07-0081, Regulatory Options for Licensing Facilities Associated with the Global Nuclear Energy Partnership, June 27, 2007. See: http://www.nrc.gov/reading-rm/doc-collections/commission/cvr/2007/2007-0081vtr.pdf

14. U.S. Nuclear Regulatory Commission, Memorandum, Annette L. Viette-Cook to Luis A. Reyes and Frank P. Gillespie, Staff Requirements-SECY-07-0081-Regulatory Options for Licensing Facilities Associated with the Global Nuclear Energy Partnership, June 27, 2007. See:

http://www.nrc.gov/reading-rm/doc-collections/commission/srm/2007/2007$0081 \mathrm{srm} . h \mathrm{tml}$

15. L. J. Koch, Experimental Breeder Reactor-II, An Integrated Experimental Fast Reactor Nuclear Power Station, Argonne National Laboratory. (Available on-line at http://www.ipd.anl.gov/anlpubs/2004/03/49168.pdf). 
16. H. V. Lichtenberger, et al, Operating Experience and Experimental Results Obtained from an NaK-Cooled Fast Reactor, Proc. Internatinal Conference on the Peaceful Uses of Atomic Energy, Vol. 3, P/813, Geneva, United Nations, August, 1955.

17. Technical Information and Hazards Summary Report, Enrico Fermi Atomic Power Plant, Power Reactor Development Company, Detroit, Michigan, June, 1961.

18. G. Billuris, et a1., SEFOR Plant Design, Fast Reactors National Topical Meeting, American Nuclear Society, San Francisco, April, 1967.

19. C. P. Cabell, A Summary Description of the Fast Flux Test Facility, HEDL-400, Hanford Engineering Development Laboratory, December, 1980.

20. D. E. Simpson, FFTF Design for Safety, Proc. Fast Reactor Safety Meeting, CONF740401-P2, pp. 1041-1060, American Nuclear Society, Beverly Hills, California, April 24, 1974.

21. D. E. Simpson, Resolution of Key Safety-Related Issues in FFTF Regulatory Review, Proc. Intl. Mtg. Fast Reactor Safety and Related Physics, CONF-761001, Vol. II, pp. 400-410, American Nuclear Society, Chicago, Illinois, October 5-8, 1976.

22. A. R. Schade and D. E. Simpson, FFTF Regulatory Review for Operating Authorization, Proc. Intl. Mtg. Fast Reactor Safety Technology, Vol. 5, pp. 2425-2430, American Nuclear Society, Seattle, Washington, August 19-23, 1979.

23. L. E. Strawbridge, Safety Related Criteria and Design Features in the Clinch River Breeder Reactor Plant, Proc. Fast Reactor Safety Meeting, CONF-740401-P1, pp. 72-92, American Nuclear Society, Beverly Hills, California, April 2-4, 1974.

24. R. J. Slember, Safety-Related Design Considerations for the Clinch River Breeder Reactor Plant, Proc. Intl. Mtg. Fast Reactor Safety and Related Physics, CONF-761001, Vol. I, pp. 112-125, American Nuclear Society, Chicago, Illinois, October 5-8, 1976.

25. L. E. Strawbridge and G. H. Clare, Exclusion of Core Disruptive Accidents from the Design Basis Accident Envelope in CRBRP, Proc. Intl. Mtg. Fast Reactor Safety, Vol. 1, pp.317-327, American Nuclear Society, Knoxville, Tennessee, April 21-25, 1985.

26. J. G. Giitter and M. W. Akhtar, An Assessment of the Clinch River Breeder Reactor Core and Containment Response to Core Disruptive Accidents, Proc. Intl. Mtg. Fast Reactor Safety, Vol. 1, pp.463-470, American Nuclear Society, Knoxville, Tennessee, April 21$25,1985$.

27. T. G. Theofanous and C. R. Bell, An Assessment of CRBR Core Disruptive Accident Energetics, , Proc. Intl. Mtg. Fast Reactor Safety, Vol. 1, pp.471-480, American Nuclear Society, Knoxville, Tennessee, April 21-25, 1985.

28. P. M. Magee, U.S. ALMR Licensing Status, Proc. Intl. Topical Mtg. Advanced Reactors Safety, Vol. 2, pp.1011-1017, American Nuclear Society, Pittsburg, Pennsylvania, April 17-21, 1994. 
Appendix A

Proposed DOE/NRC GNEP Closed Fuel Cycle Topical Seminar Areas

February 5 NRC Mark-Up (Bold type)

1. Overview and Sodium Technology Background

a. Introduction to LMR Technology; LMR experience, designs, performance, operational issues, safety issues, US and international, status. US R\&D program and experience.

b. Sodium technology, chemistry, thermal-hydraulic performance, corrosion of steel, oxidation

2. Physics and Thermal-Hydraulics Performance

a. Fast reactor physics performance; breeding, burning, mass loadings/inventory, coolant void worth, and reactivity coefficients

b. Fast reactor thermal-hydraulic performance; temperatures, heat fluxes, forced convection, natural circulation, etc.

3. Fuel Performance Experience
a. Fuel performance - general; metal and oxide
b. Fuel irradiation experience and results; EBR-II, FFTF
c. TREAT testing results for metal and oxide fuel
d. Fabrication \& standards history/current capabilities

4. Structures, Systems, and Components \#1

a. Major sodium component technology; pumps, heat exchangers, vessels, refueling systems design and performance, etc.

b. Structural materials for SFR technology and their performance

c. I\&C, fire protection, sodium leak detection, etc.

d. Prior and current operating experience (availability?)

5. Structures, Systems, and Components \#2
a. Control and protection systems designs and performance
b. Containment systems designs and performance
c. Seismic isolation systems and reactor applications
d. Prior and current operating experience (availability?)

6. Safety Issues \#1
a. Safety issues; DBA, BDBA, severe accident historically (coolant void, recriticality, FCI), passive safety
b. Safety analysis past results (FFTF, CRBRP, SAFR, PRISM)
c. Safety analysis methods; reactor, structural, coolant aerosols, containment

\section{Safety Issues \#2}


a. Licensing issues in FFTF, CRBRP, SAFR, PRISM. International experience in perspective, high profile issues in Phenix, SuperPhenix, MONJU, BN-350, EBR-1, FERMI explained and lessons learned.

b. Inherent passive safety characteristics of sodium fast reactor systems (wrt loss of flow without scram, etc.). Inherent reactivity shutdown, natural circulation decay heat removal

c. Safety testing results, EBR-II SHRT, FFTF ULOF (GEMS); TREAT

\section{Codes, Modeling, Analyses}

a. Computer Codes Used for Transient and Accident Analyses of LMRs

b. Mechanistic Source Term Modeling for LMRs

c. General - status of other codes, modeling, analyses; need for updating or new applications; access to data and codes, etc.

9. Licensing Strategy/Framework

a. DOE - Applicant/Licensee

- Relationship

- Responsibilities

- Contractual Requirements

b. Applicability of DOE Orders

c. NRC Regulatory Requirements

- Technical Requirements

- Material, SSC Specifications

- Safety Program

- QA Program

- Fuel Technical Criteria and Qualification

d. Recycle/Fabrication/Reactor Operations/Safety/Quality Interactions 


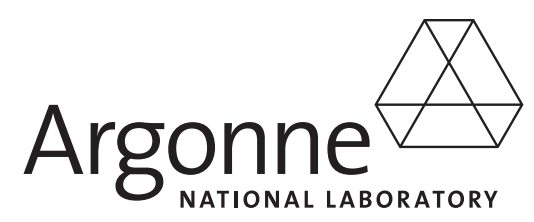

Nuclear Engineering Division

Argonne National Laboratory

9700 South Cass Avenue, Bldg. 208

Argonne, IL 60439-4842

www.anl.gov 